\title{
ANALISIS HUBUNGAN KARAKTERISTIK SOSIO-EKONOMI DENGAN KETAHANAN PANGAN IKANI: Pendekatan Model Product Moment Correlation
}

\author{
Lindawati ${ }^{1}$ dan Risna Yusuf ${ }^{1}$ \\ ${ }^{1}$ Peneliti pada Balai Besar Riset Sosial Ekonomi Kelautan dan Perikanan \\ JI. KS. Tubun Petamburan VI, Jakarta 10260 \\ Telp. 021 53650162/Fax. 02153650159
}

\begin{abstract}
ABSTRAK
Penelitian bertujuan untuk menganalisis hubungan karakteristik sosial ekonomi dengan ketahanan pangan ikani yang telah dilakukan pada bulan Juni sampai dengan Agustus 2008. Penelitian ini menggunakan pendekatan non parametrik dengan menggunakan model Product Moment Correlation. Responden dipilih menggunakan metode proportional random sampling berdasarkan jenis alat tangkap. Secara umum hasil penelitian menunjukkan terdapat hubungan yang nyata antara karakteristik sosial ekonomi yaitu peubah pendidikan, budaya makan ikan, nilai aset dan pendapatan berhubungan positif dan nyata dengan tingkat ketahanan pangan ikani rumah tangga perikanan tangkap laut skala kecil. Berdasarkan hasil penelitian dapat disarankan bahwa pemerintah dapat meningkatkan ketahanan pangan ikani melalui peningkatan mutu pendidikan dan pengetahuan pangan dan gizi, budaya makan ikan, pendapatan rumah tangga dan aset rumah tangga.
\end{abstract}

Kata Kunci: Karakteristik Sosial Ekonomi, Ketahanan Pangan Ikani, Nelayan

Abstract: Analysis of the Relationship between Socio Economic Characteristics and Fish-Food Security: Product Moment Correlation Model Approach. By : Lindawati and Risna Yusuf

Research aimed at analyzing the relation between socio-economic characteristics and fish-food security was carried out during June to August 2008. The research was using non-parametric approach with the property of Product Moment Correlation model. Respondents representing variety of fishing unit being used were chosen using proportional random sampling method. In general, the study showed that there was significantly relationship between socio-economic characteristic and fish-food security especially education, eating fish culture, asset value and income on small scale capture fisheries industry. Base on the study, it can be suggested they the government could increase fish-food security through improvement programs on education and knowledge of food and nutrition, eating fish culture, income and asset value.

Keywords: Socio Economic Characteristics, Fish-Food Security, Fisher 


\section{PENDAHULUAN}

Masalah pangan dalam konteks perkembangan bangsa sangat penting, karena ketersediaan pangan merupakan pilar penting bagi kedaulatan sebuah bangsa. Pangan merupakan salah satu kebutuhan yang harus terpenuhi, karena pemenuhan kebutuhan terhadap pangan merupakan hak yang paling asasi bagi setiap orang yang akan berpengaruh pada terwujudnya sumberdaya manusia yang berkualitas untuk melaksanakan pembangunan. Menurut Undang-undang Nomor 7 Tahun 1996 tentang pangan, mendefinisikan bahwa ketahanan pangan merupakan kondisi terpenuhinya pangan bagi setiap rumah tangga, yang tercermin dari tersedianya pangan yang cukup jumlah maupun mutunya, aman, merata dan terjangkau.

Menurut Sawit (2007) bahwa penentu ketahanan pangan di tingkat rumah tangga adalah akses terhadap pangan, ketersediaan pangan dan resiko yang terkait dengan kedua tersebut. Menurut Dewan Ketahanan Pangan yang disampaikan pada acara Lokakarya Widyakarya Nasional Pangan dan Gizi IX (WNPG), ketahanan pangan secara nasional dapat diartikan sebagai kemampuan suatu bangsa untuk menjamin seluruh penduduknya memperoleh pangan yang cukup, mutu yang layak, aman yang didasarkan pada optimalisasi pemanfaatan dan berbasis pada keragaman sumberdaya lokal. Ketahanan pangan selain sebagai prasyarat untuk memenuhi hak asasi pangan masyarakat, juga merupakan pilar bagi kelangsungan dan kedaulatan suatu bangsa dan negara. Oleh karena itu, penguatan dalam bidang kelembagaan ketahanan pangan di masyarakat dan pemerintah sangat berperan strategis.

Permasalahan ketahanan pangan mengalami kompleksitas di semua aspek pembangunan yang dapat mengancam ketersediaan pangan di kemudian hari. karena masih banyak ditemuinya masalah rawan pangan dan rawan gizi karena belum optimalnya sistem produksi pangan, distribusi pangan, kehidupan sosial ekonomi maupun status gizi masyarakat. Pemenuhan kondisi ketahanan pangan dan gizi penduduk tidak hanya membutuhkan peningkatan produksi pangan tetapi juga aspek-aspek yang berkaitan dengan masalah distribusi, kualitas dan pola konsumsi masyarakat. Berdasarkan definisi ketahanan pangan dari UU RI No. 7 tahun 1996, ada 4 (empat) komponen yang harus dipenuhi untuk mencapai kondisi ketahanan pangan yaitu (1) kecukupan ketersediaan pangan; (2) stabilitas ketersediaan pangan tanpa fluktuasi dari musim ke musim atau dari tahun ke tahun; (3) aksesibilitas/keterjangkauan terhadap pangan dan (4) kualitas/keamanan pangan.

Berdasarkan Undang-undang Nomor 7 Tahun 1996, sasaran ketahanan pangan adalah masyarakat yang mampu mengkonsumsi pangan dan gizi dalam jumlah yang seimbang dan baik. Sehingga pemilihan pangan protein khususnya dari sumber hewani (dalam hal ini ikan) merupakan salah satu alternatif pilihan untuk memenuhi kebutuhan akan pangan. Oleh karena itu, permasalahan ketersediaan, stabilitas, aksesibiltas dan keamanan pangan dari sumber ikani yang dikonsumsi oleh masyarakat merupakan salah satu fokus kajian penting berkaitan dengan ketahanan pangan di Indonesia. Berkaitan dengan hal tersebut, penelitian ini dilakukan dengan tujuan untuk menganalisis hubungan karakteristik sosial ekonomi dengan ketahanan pangan ikani pada rumah tangga perikanan tangkap laut skala kecil. Hasil penelitian ini diharapkan dapat berguna sebagai bahan masukan kepada pembuat kebijakan (policy maker) terkait dengan upaya meningkatkan ketahanan pangan nasional khususnya dari sumber protein hewani ikan pada rumah tangga perikanan tangkap skala kecil. 


\section{METODOLOGI}

\section{Pemilihan Lokasi dan Waktu Penelitian}

Lokasi penelitian dilakukan dengan mengambil kasus di Desa Kalibaru, Kecamatan Cilincing, Jakarta Utara dengan pertimbangan bahwa desa tersebut merupakan salah satu desa pesisir yang sebagian besar masyarakatnya bermata pencaharian sebagai nelayan pada perikanan tangkap skala kecil. Penelitian dilakukan pada bulan Juni sampai dengan Agustus 2008.

\section{Penentuan Responden Sampel}

Responden penelitian ini adalah rumah tangga nelayan sebagai unit analisisnya. Topik penelitian sangat terkait erat dengan keputusan ibu rumah tangga dalam mengkonsumsi pangan, responden rumah tangga adalah ibu rumah tangga nelayan perikanan tangkap laut skala kecil yang kepala rumah tangganya bekerja sebagai nelayan dengan menggunakan kapal motor tempel berbobot di bawah 5 gross ton (GT). Sebagian besar $(85 \%)$ nelayan di daerah tersebut adalah nelayan perikanan tangkap skala kecil. Jumlah responden mencapai 31 responden yang dipilih dengan menggunakan metoda propotion random sampling berdasarkan jenis alat tangkap.

\section{Jenis dan Sumber Data}

Jenis data yang digunakan dalam penelitian ini adalah data primer. Data primer diperoleh dari hasil wawancara dengan menggunakan kuesioner yang meliputi karakteristik sosial ekonomi baik pendidikan, budaya makan ikan, nilai penggunaan aset, jumlah pendapatan, jumlah pengeluaran yang berhubungan dengan ketahanan pangan.

\section{Metode Analisis Data}

Data yang diperoleh dalam penelitian ini selanjutnya dianalisis dengan menggunakan pendekatan statistik non-parametrik dengan model Product Moment Correlation atau lebih dikenal dengan Pearson Product Moment Correlation. Korelasi ini digunakan untuk menggambarkan seberapa erat hubungan linear antara peubah-peubah yang dianalisis. Peubah-peubah yang akan dianalisis meliputi beberapa aspek, yaitu tingkat pendidikan, budaya makan ikan, tingkat pendapatan, aset ekonomi dan tingkat ketahanan pangan ikani rumah tangga pada nelayan di Desa Kalibaru, Kecamatan Cilincing, Jakarta Utara. Aspekaspek tersebut merupakan perwakilan dari karakteristik sosial ekonomi dalam mendukung ketahanan pangan dari sumber ikani. Pengolahan data dilakukan dengan menggunakan bantuan software SPSS versi 16.

Adapun rumusnya adalah sebagai berikut (Siegel, 1996):

$$
r X Y=\frac{N \sum X Y-\left(\sum X\right)\left(\sum Y\right)}{\sqrt{N \sum X^{2}-\left(\sum X\right)^{2} \sqrt{N \sum Y^{2}-\left(\sum Y\right)^{2}}}}
$$

keterangan:

$\mathrm{rXY}=$ Korelasi antara $\mathrm{X}$ dan $\mathrm{Y} /$ Corelation $X$ and $Y$

$\mathrm{N}=$ = Jumlah subyek/Total subject

$\mathrm{X}=$ Skor total/Total Score

$\mathrm{Y}=$ Skor item/ltem score

\section{HASIL DAN PEMBAHASAN}

\section{Deskripsi Perikanan di Desa Kalibaru,} Kecamatan Cilincing, Jakarta Utara

Sektor perikanan merupakan salah satu sumber mata pencaharian utama bagi masyarakat di wilayah Jakarta Utara, dimana sebagian besar penduduk yang berada di wilayah tersebut memiliki mata pencaharian yang utama sebagai nelayan dan pembudidaya kerang hijau. Penduduk tersebut sebagian besar tinggal di Desa Kalibaru Kecamatan Cilincing dimana jumlah nelayannya sebesar $39 \%$ dari 45.212 jiwa (Anonim, 2007). Nelayan-nelayan tersebut sebagian besar juga merupakan nelayan skala kecil yang memiliki kapal motor tempel dengan bobot di bawah $5 \mathrm{GT}$. 


\section{Deskripsi Karakteristik Sosial Ekonomi}

\section{Tingkat Pendidikan}

Pendidikan merupakan faktor yang penting dalam keluarga. Pendidikan di samping merupakan modal utama dalam menunjang perekonomian rumah tangga juga berperan dalam pola penyusunan makanan untuk rumah tangga. Tingkat pendidikan formal dalam rumah tangga berhubungan positif dengan perbaikan dalam pola konsumsi pangan keluarga dan pola pemberian makanan pada bayi dan anak. Tingkat pendidikan akan mempengaruhi konsumsi melalui pemilihan bahan pangan. Orang yang berpendidikan lebih tinggi cenderung memilih makanan yang lebih baik dalam jumlah dan mutunya dibandingkan mereka yang berpendidikan lebih rendah. Akan tetapi tingkat pendidikan umum yang lebih tinggi tanpa disertai dengan pengetahuan di bidang gizi terutama ibu, ternyata tidak berpengaruh terhadap pemilihan makanan untuk keluarga (Mangkunegara, 2003).

Pada Gambar 1 dan 2 memperlihatkan tingkat pendidikan pada jumlah rumah tangga perikanan tangkap skala kecil yang di survey. Pada gambar tersebut terlihat bahwa tingkat pendidikan nelayan dalam hal ini kepala keluarga yang tidak tamat Sekolah Dasar (SD) memiliki jumlah yang tertinggi yaitu sebesar 14 orang, sedangkan nelayan yang tamat SMP dan tamat SMA memiliki jumlah yang paling sedikit, yaitu hanya 1 (satu) orang. Sedangkan tingkat pendidikan responden dalam hal ini ibu rumah tangga menunjukkan tingkat pendidikan yang tidak jauh berbeda dengan kepala keluarga, yaitu sebanyak 16 orang yang tidak tamat SD, dan yang tamat SMP hanya 5 (lima) orang. Dari gambaran tersebut terlihat bahwa tingkat pendidikan pada rumah tangga perikanan tangkap skala kecil di Cilincing masih tergolong rendah, sehingga akan mempengaruhi dalam pola konsumsi pangan keluarga, sehingga sering kita dengar bahwa masalah rawan gizi sering terjadi pada masyarakat nelayan, padahal mereka pekerjaan sehari-harinya menangkap ikan. Hal ini terjadi karena hasil tangkapan yang mereka peroleh yang kualitasnya bagus akan dijual, sedangkan mereka memilih mengkonsumsi ikan yang kualitasnya rendah.

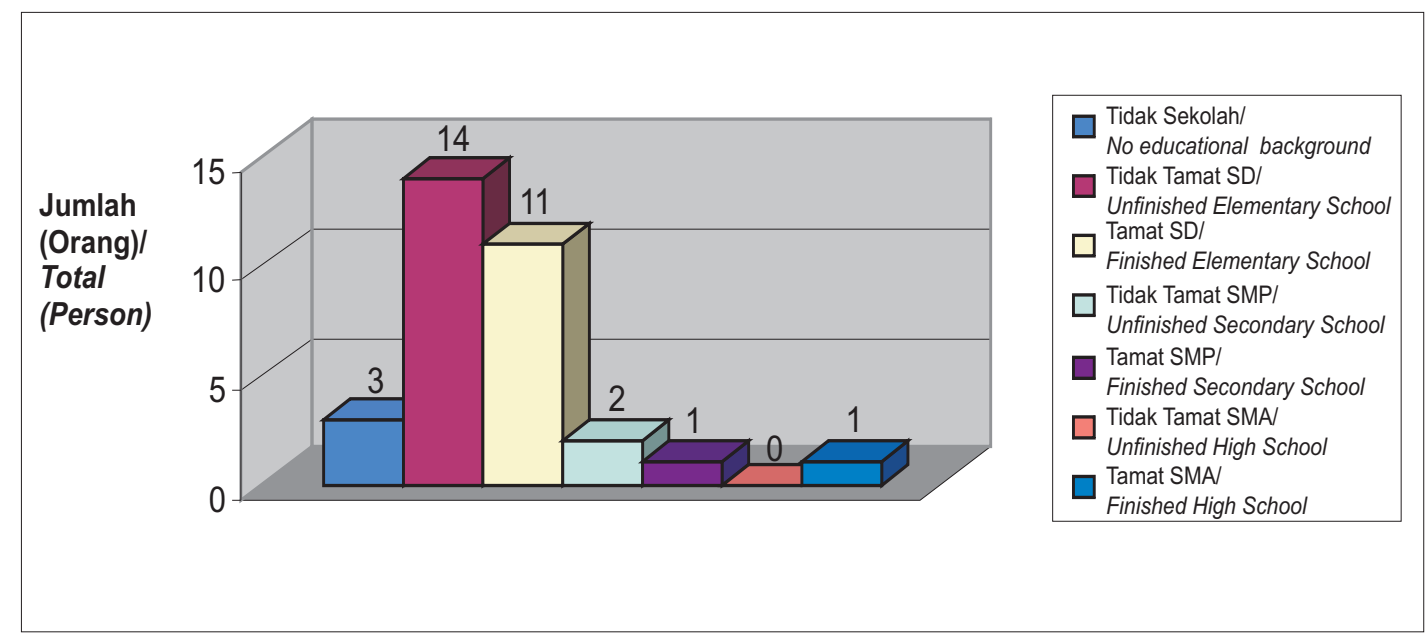

Gambar1. Tingkat Pendidikan Nelayan pada RTPT Laut Skala Kecil di Kecamatan Cilincing, Jakarta Utara, 2008.

Figure 1. Educational background of Small-scale Fisheries Household in Subdistrict of Cilincing, North Jakarta, 2008. 


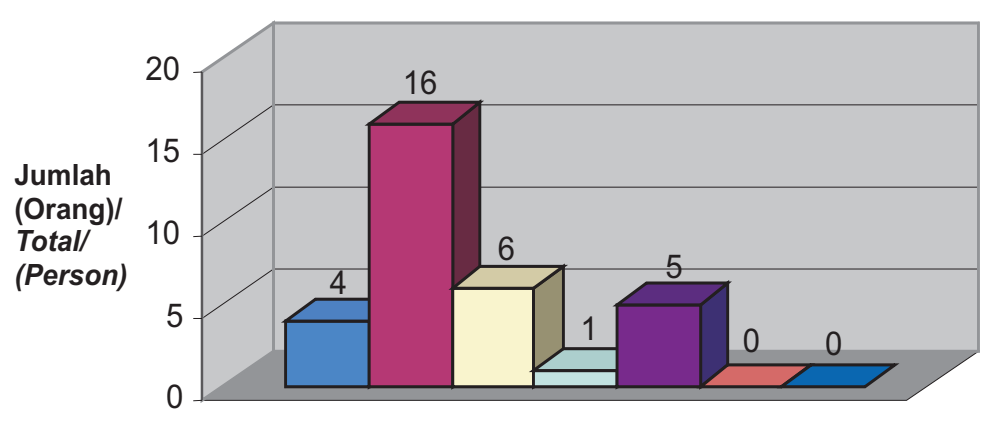

Tidak Sekolah

No educational background

Tidak Tamat SD/

Unfinished Elementary School

Tamat SD/

Finished Elementary School

Tidak Tamat SMPI

Unfinished Secondary School

Tamat SMPI

Finished Secondary School

Tidak Tamat SMAI

Unfinished High School

Tamat SMA/

Finished High School

\section{Gambar 2. Tingkat Pendidikan Responden pada RTPT Laut Skala Kecil di Kecamatan} Cilincing, Jakarta Utara, 2008.

Figure 2. Education of Respondent of Small-scale Fisheries Household in Subdistrict of Cilincing, North Jakarta, 2008.

Selain itu, karena masih kurangnya pendidikan dan pengetahuan responden akan pentingnya arti gizi khususnya dari protein hewani dalam pemenuhan kebutuhan seharihari. Disamping itu, berdasarkan hasil wawancara apabila anak-anak mereka sudah cukup dewasa (terutama anak laki-laki) tidak perlu melanjutkan pendidikan yang lebih tinggi karena mereka sudah diberi kewajiban untuk mencari nafkah sebagai nelayan ataupun ikut membantu pekerjaan orang tuanya.

\section{Budaya Makan Ikan}

Budaya makan ikan (preferensi) pada rumah tangga perikanan tangkap skala kecil dapat dilihat dari seberapa kuatnya budaya makan ikan yang ada pada rumah tangga tersebut. Untuk melihat budaya makan ikan ini dapat dilihat dari preferensi rumah tangga dalam memilih sumber protein hewani seperti ikan, daging (ayam/sapi) dan telur. Jadi preferensi ini dilihat sumber protein hewani mana yang pertama kali dipilih oleh rumah tangga tersebut jika seandainya ketiga menu tersebut dihidangkan. Sehingga, apabila rumah tangga tersebut memilih ikan sebagai pilihan pertama, hal ini berarti bahwa sangat kuatnya budaya makan yang ada pada rumah tangga perikanan tersebut. Akan tetapi jika seandainya pilihan menu tersebut selain ikan, ini berarti bahwa budaya makan ikan pada rumah tangga tersebut belum kuat.

Berdasarkan Gambar 3 dapat dilihat bahwa preferensi sumber protein hewani pada rumah tangga perikanan tangkap skala kecil di Cilincing apabila ketiga sumber protein hewani (daging, ikan, telur) dihidangkan. Dari hasil wawancara dapat dilihat presentasi yang diperoleh yaitu sebesar $68 \%$ rumah tangga memilih daging sebagai sumber proteinnya, $19 \%$ memilih ikan, dan $13 \%$ memilih telur. Dari presentasi tersebut terlihat, bahwa rumah tangga perikanan tangkap skala kecil di Cilincing memilih daging sebagai sumber proteinnya, hal ini berarti bahwa budaya makan ikan pada rumah tangga tersebut belum kuat. Sehingga, meskipun mereka menangkap ikan, tetapi jika dihadapkan pada ketiga menu tersebut mereka lebih memilih daging, dengan alasan untuk variasi menu agar tidak bosan.

Pada Gambar 4 terlihat bahwa jika harga ikan yang dibeli lebih mahal dari biasa yang mereka beli, maka rumah tangga perikanan 


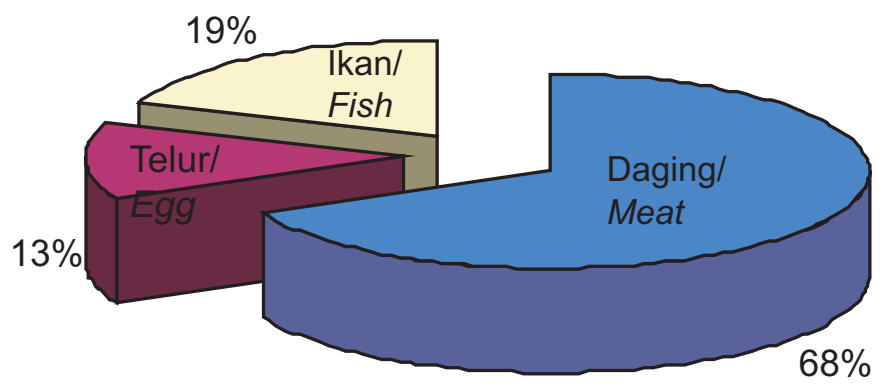

Gambar 3. Preferensi Sumber Protein Hewani oleh RTPT Laut Skala Kecil di Kecamatan Cilincing, Jakarta Utara, 2008.

Figure 3. Protein Preference of the Small-scale Fisheries Household in Subdistrict of Cilincing, North Jakarta , 2008.

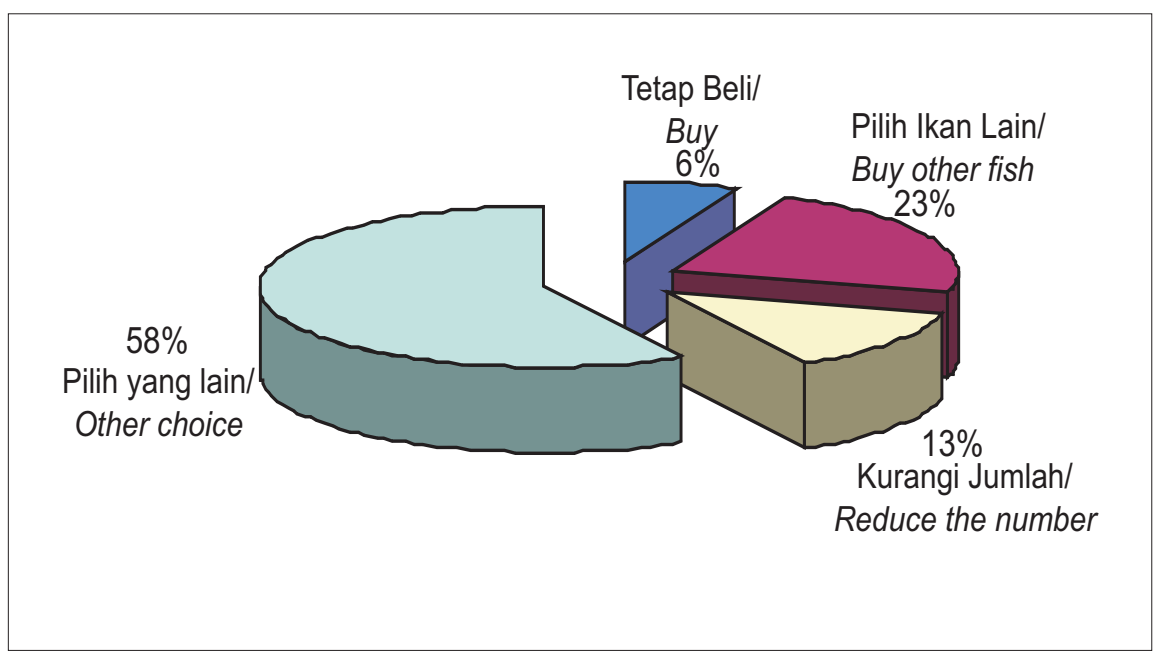

Gambar 4. Hal yang dilakukan oleh RTPT Skala Kecil Jika Harga Ikan Mahal di Kecamatan Cilincing, Jakarta Utara, 2008.

Figure 4. Things to do by Small-Scale Fisheries Household Whenever expensive Fish Price Occurs in subdistrict of Cilincing, North Jakarta, 2008.

tangkap skala kecil di Cilincing lebih memilih pangan lain selain ikan sebagai penggantinya, hal ini dapat dilihat dari presentasi yang diperoleh yaitu sebesar $58 \%$, sedangkan yang tetap membeli ikan meskipun harga ikan tersebut mahal hanya sebesar $6 \%$. Hal ini mengindikasikan bahwa budaya makan ikan pada rumah tangga perikanan tangkap skala 
kecil di Cilincing belum cukup kuat, meskipun sebanyak $23 \%$ responden tetap memilih mengkonsumsi ikan lain (yang lebih murah) meskipun harga ikan yang biasa mereka beli mahal, hal ini mengindikasikan bahwa tingkat pendidikan mempengaruhi dalam pemenuhan konsumsi pangan.

\section{Aset Ekonomi}

Aset ekonomi merupakan salah satu indikator dalam karakteristik sosial ekonomi yang mendukung dalam ketahanan pangan. Gambar 5 memperlihatkan jumlah aset yang dimiliki oleh rumah tangga perikanan tangkap skala kecil yang berada di Cilincing. Dari gambar tersebut dapat dilihat bahwa aset televisi merupakan aset yang paling banyak televisi karena jika musim paceklik atau hasil tangkapan tidak memadai maka aset-aset ini bisa dijual untuk memenuhi kebutuhan hidup rumah tangga tersebut.

\section{Tingkat Pendapatan}

Pendapatan keluarga adalah jumlah semua hasil perolehan yang didapat oleh anggota keluarga dalam bentuk uang sebagai hasil pekerjaannya. Pendapatan keluarga meliputi penghasilan ditambah dengan hasilhasil lain. Pendapatan keluarga mempunyai peran yang penting terutama dalam memberikan efek terhadap taraf hidup mereka. Efek di sini lebih berorientasi pada kesejahteraan dan kesehatan, dimana perbaikan pendapatan akan meningkatkan

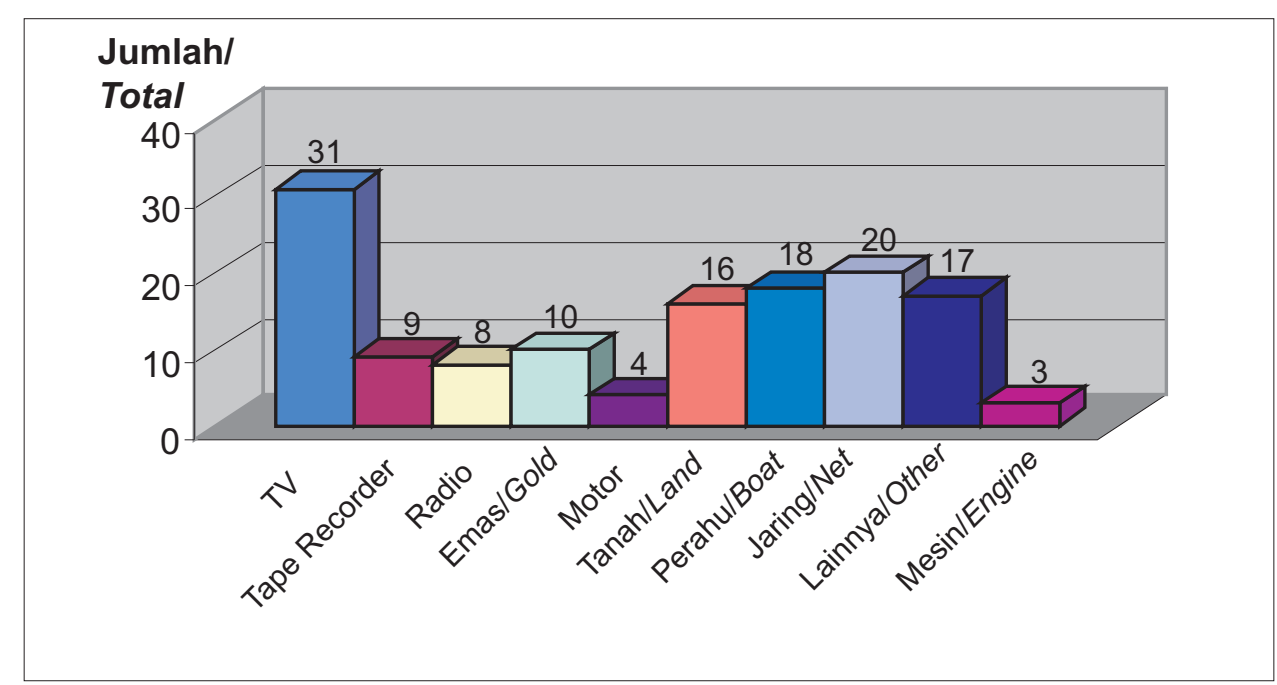

\section{Gambar 5. Aset yang Dimiliki RTPT Skala Kecil di Kecamatan Cilincing, Jakarta Utara, 2008.}

Figure 5. Assets Owned by Small-scale Fisheries Household in Subdistrict of Cilincing, North Jakarta, 2008.

dimiliki yaitu sebanyak 31 orang, sedangkan aset yang paling sedikit yang dimiliki yaitu mesin dan motor yaitu masing-masing sebanyak 3 (tiga) dan 4 (empat) orang. Hal ini menunjukkan bahwa rumah tangga tersebut memiliki aset ekonomi yang memiliki nilai jual yang tinggi seperti emas, tape recorder dan tingkat gizi masyarakat. Pendapatan akan menentukan daya beli terhadap pangan dan fasilitas lain (pendidikan, perumahan, kesehatan, dan lain-lain) yang dapat mempengaruhi status gizi. Pendapatan merupakan penentu utama yang berhubungan dengan kualitas makanan. Apabila 
penghasilan keluarga meningkat, penyediaan lauk pauk akan meningkat pula mutunya. Selain itu, terdapat hubungan antara pendapatan dan keadaan status gizi. Hal itu karena tingkat pendapatan merupakan faktor yang menentukan kuantitas dan kualitas makanan yang dikonsumsi. Sejak lama telah disepakati bahwa pendapatan merupakan hal utama yang berpengaruh terhadap kualitas menu. Pernyataan itu nampak seperti logis, karena memang tidak mungkin orang makan makanan yang tidak sanggup dibelinya. Pendapatan yang rendah menyebabkan daya beli yang rendah pula, sehingga tidak mampu membeli pangan dalam jumlah yang diperlukan, keadaan ini sangat berbahaya untuk kesehatan keluarga dan akhirnya dapat berakibat buruk terhadap keadaan status gizi terutama bagi bayi dan balita. Dalam kaitannya dengan status gizi, pendapatan mempunyai hubungan yang erat dengan perubahan dan perbaikan konsumsi pangan, tetapi pendapatan yang tinggi belum tentu menjamin keadaan gizi yang baik. Pertambahan pendapatan tidak selalu membawa perbaikan pada konsumsi pangan, karena walaupun banyak pengeluaran uang untuk pangan, mungkin akan makan lebih banyak, tetapi belum tentu kualitas pangan yang dibeli lebih baik. Dari uraian tersebut di atas dapat diketahui bahwa antara pendapatan dan gizi, jelas ada hubungan yang menguntungkan. Berlaku hampir universal, peningkatan pendapatan akan berpengaruh terhadap perbaikan kesehatan dan kondisi keluarga dan selanjutnya berhubungan dengan status gizi. Namun peningkatan pendapatan atau daya beli seringkali tidak dapat mengalahkan pengaruh kebiasaan makan terhadap perbaikan gizi yang efektif (Anonim, 2000).

Pada Gambar 6 terlihat jumlah pendapatan rumah tangga perikanan tangkap skala kecil di Cilincing dalam satu tahun. Dari gambar tersebut terlihat bahwa pendapatan rumah tangga antara $\mathrm{Rp}$. 8.706.600,- sampai dengan Rp. 12.330.000,- mempunyai presentase paling besar yaitu $44 \%$, sedangkan jumlah pendapatan yang lebih dari Rp. 12.333.000,- sebesar 22\%. Jumlah pendapatan tersebut tergantung pada hasil

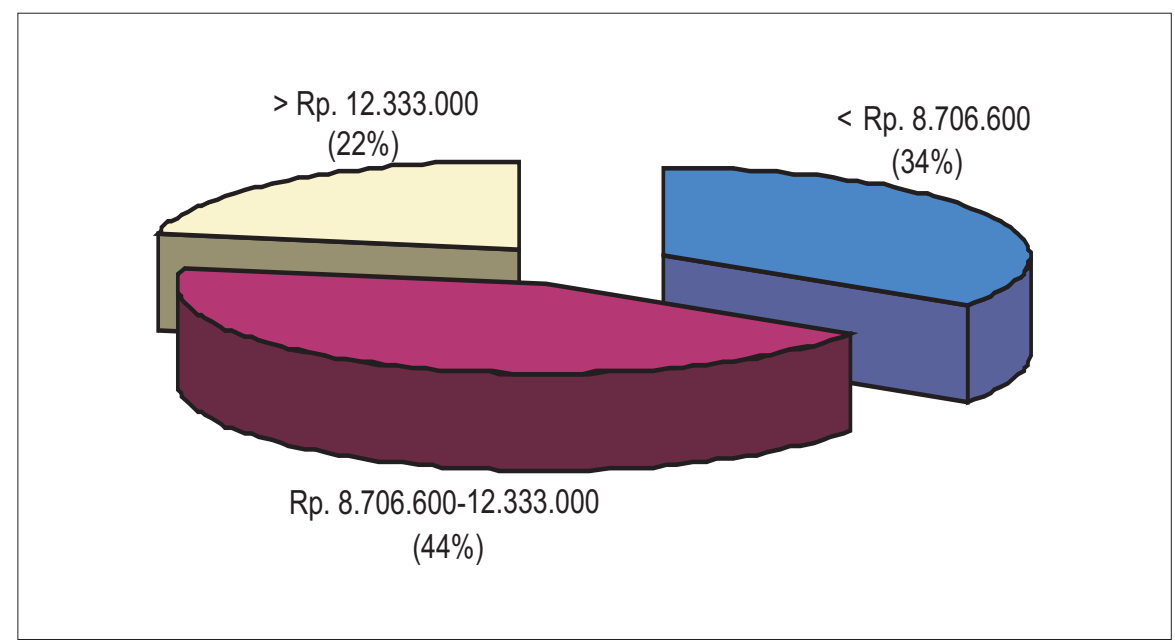

Gambar 6. Tingkat Pendapatan per Tahun pada RTPT Laut Skala Kecil di Kecamatan Cilincing, Jakarta Utara, 2008.

Figure 6. Annual Income of the Small-scale Fisheries Household in Subdistrict of Cilincing, North Jakarta, 2008. 
tangkapan yang diperoleh pada setiap musimnya, baik musim paceklik, normal maupun along. Dengan demikian, pendapatan rumah tangga di Cilincing dalam setahun termasuk dalam kategori yang merata, sehingga dengan pendapatan tersebut diharapkan dapat terpenuhinya kebutuhan akan pangan khususnya dari sumber ikani.

Gambar 7 memperlihatkan pendapatan rumah tangga perikanan tangkap skala kecil pada masa paceklik. Pada gambar tersebut dapat dilihat bahwa persentase terbesar yaitu $41 \%$ adalah rumah tangga yang memiliki pendapatan antara Rp. 286.600,- samapi dengan Rp. 473.300,- sedangkan persentase terkecil yaitu $25 \%$ adalah rumah tangga yang memiliki pendapatan kurang dari Rp. 286.600,- . Hal ini menujukkan bahwa pada masa paceklik jumlah ikan dari hasil tangkapan relatif sangat sedikit sehingga pendapatan yang diterima oleh nelayan yang mata pencahariannya hanya sebagai nelayan juga sangat kecil. Dari kondisi yang terjadi di lapangan terlihat bahwa walaupun masih dalam musim paceklik dimana jumlah ikan yang diperoleh terbatas karena dipengaruhi oleh iklim laut yang tidak menentu, nelayan tersebut tidak berupaya mencari penghasilan lain untuk menutupi kebutuhan sehari-hari sehingga yang terjadi rumah tangga tersebut sangat terbatas dalam memenuhi kebutuhan sehari-hari.

Gambar 8 memperlihatkan pendapatan rumah tangga perikanan tangkap skala kecil pada masa normal. Pada gambar tersebut dapat dilihat bahwa persentase pendapatan yang kurang dari Rp. 770.000,- dengan pendapatan antara Rp. 770.000,- sampai dengan Rp. 1.120.000,- mempunyai persentase masing-masing sebesar $50 \%$ dan $47 \%$, sedangkan pendapatan yang lebih dari Rp. 1.120.000,- hanya sebesar 3\% Hal ini menunjukkan bahwa pada musim ini jumlah tangkapan yang diperoleh nelayan lebih banyak dibandingkan dengan jumlah tangkapan yang diperoleh pada musim paceklik. Dengan jumlah tangkapan yang lebih banyak ini maka pendapatan nelayan juga lebih banyak dibandingkan pada musim paceklik.

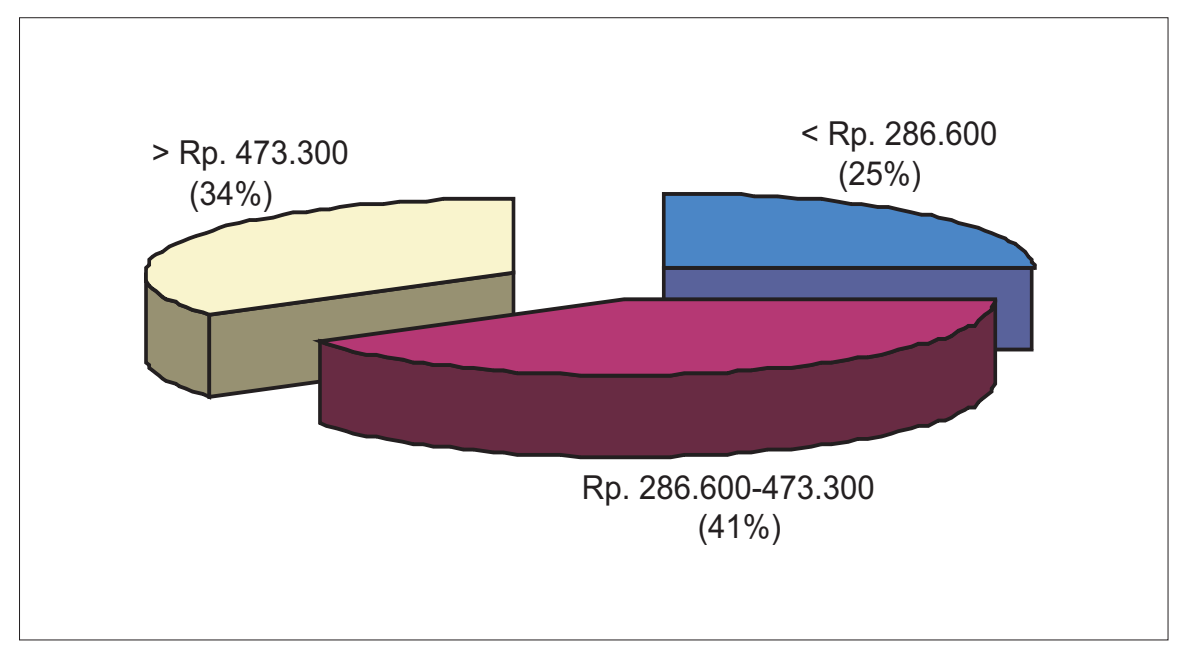

Gambar 7. Tingkat Pendapatan pada RTPT Laut Skala Kecil pada Musim Paceklik di Kecamatan Cilincing, Jakarta Utara, 2008.

Figure 7. Income Level of the Small-scale Fisheries Household at Famine Season in Subdistrict of Cilincing, North Jakarta, 2008. 
Rp. $770.000-1.120 .000$

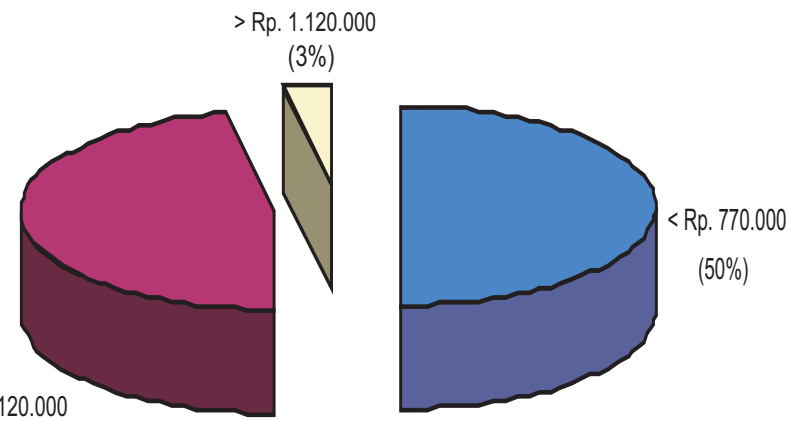

$(47 \%)$

Gambar 8. Tingkat Pendapatan pada RTPT Laut Skala Kecil pada Musim Normal di Kecamatan Cilincing, Jakarta Utara, 2008.

Figure 8. Income Level of the Small-scale Fisheries Household at Normal Season in Subdistrict of Cilincing, North Jakarta, 2008.

Pada Gambar 9 memperlihatkan pendapatan rumah tangga perikanan tangkap skala kecil pada masa "Along". Pada gambar tersebut dapat dilihat bahwa rumah tangga yang memiliki persentase terbesar yaitu 53\% adalah rumah tangga yang memiliki pendapatan kurang dari Rp.1.283.300,- sedangkan persentase terkecil yaitu $22 \%$ adalah rumah tangga yang memiliki pendapatan antara Rp. 1.283.300,- sampai dengan Rp. 2.066.600,- . Hal ini terjadi karena jumlah ikan hasil tangkapan sangat banyak dan jenis ikan hasil tangkapan juga bervariasi sehingga hal ini memungkinkan tingkat

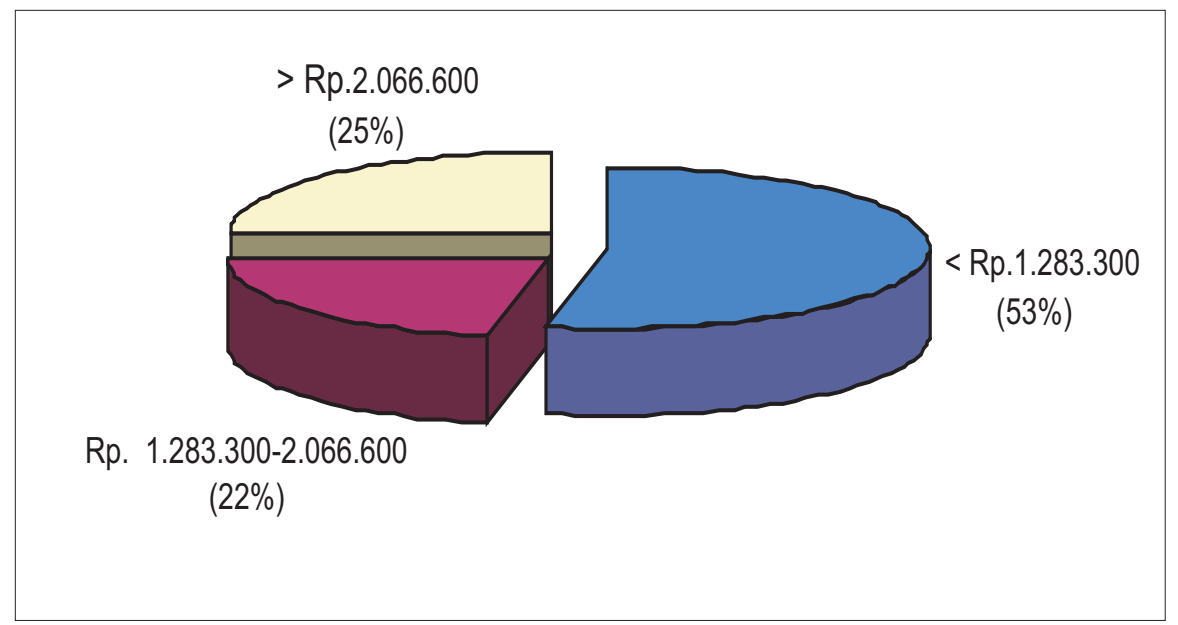

Gambar9. Tingkat Pendapatan RTPT Laut Skala Kecil pada Musim Puncak di Kecamatan Cilincing, Jakarta Utara, 2008.

Figure 9. Income Level of the Small-scale Fisheries Household at Peak Season in Subdistrict of Cilincing, North Jakarta, 2008. 
penjualan ikan yang tinggi dengan harga ikan yang kompetitif menyebabkan pendapatan nelayan skala kecil tersebut juga meningkat.

Pada Gambar 10 dapat dilihat bahwa berdasarkan total pengeluaran pada rumah tangga perikanan tangkap skala kecil di daerah Tuban, Jawa Timur, ternyata rumah tangga dengan total pengeluaran lebih dari Rp.1.100.000,- memiliki persentase terbesar yaitu sebesar $56 \%$, sedangkan rumah tangga dengan total pengeluaran kurang dari Rp. 700.000,- memiliki persentase terendah sebesar $6 \%$. Hal ini menjelaskan bahwa rumah tangga nelayan di Cilincing memiliki budaya hidup yang konsumtif.

Pada Gambar 11 memperlihatkan bahwa pengeluaran untuk ikan pada rumah tangga perikanan tangkap skala kecil di daerah

$>$ Rp. 1.100 .000

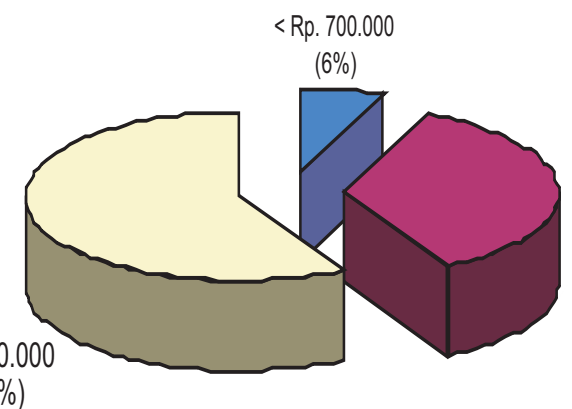

$<$ Rp. $700.000-1.100 .000$

$(35 \%)$

$(59 \%)$

Gambar 10. Total Pengeluaran pada RTPT Laut Skala Kecil di Kecamatan Cilincing, Jakarta Utara, 2008.

Figure 10. Total Expenditure of the Small-scale Fisheries Household in Subdistrict of Cilincing, North Jakarta, 2008.

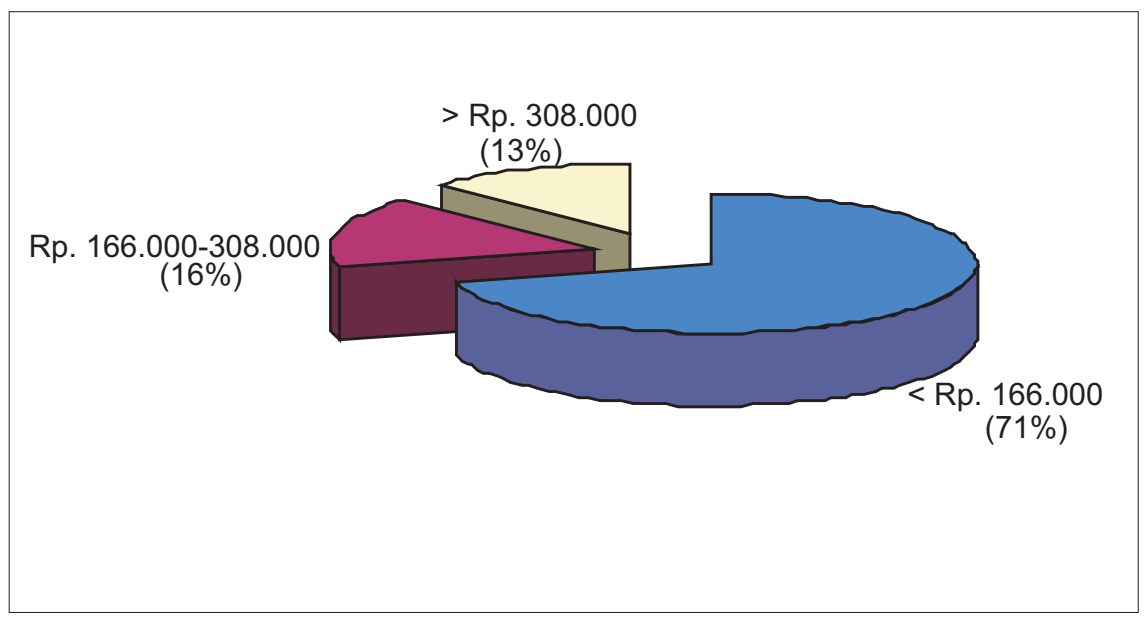

Gambar 11. Pengeluaran untuk Ikan pada RTPT Laut Skala Kecil di Kecamatan Cilincing, Jakarta Utara, 2008.

Figure 11. Expenditure for Fish of the Small-scale Fisheries Household in Subdistrict of Cilincing, North Jakarta, 2008. 
Cilincing yang paling dominan pada rumah tangga yang pendapatannya kurang dari Rp. 166.000, sedangkan pendapatan yang lebih dari Rp. 308.000,- hanya sebesar 13\%, Dengan angka tersebut terlihat bahwa jumlah pengeluaran untuk ikan relatif rendah persentasenya dari total pengeluaran. Ini menunjukkan bahwa sebagian besar rumah tangga perikanan tangkap skala kecil di wilayah Cilincing tersebut dalam mengkonsumsi ikan tidak mengeluarkan uang, akan tetapi ikan yang dikonsumsi oleh rumah tangga tersebut sebagian besar berasal dari hasil tangkapan. ketahanan pangan diklasifikasikan menjadi tiga kategori, yaitu rendah, sedang dan tinggi. Dari hasil pengolahan data ternyata skor yang diperoleh secara keseluruhan sebesar 32,35. Skor relatif untuk tahan pangan berkisar antara 33,67-46,00, sedangkan cukup tahan berkisar antara 21,34-33,66 dan rentan pangan berkisar antara 9,00-21,33.

Seperti terlihat pada Tabel 1, kondisi ketahanan pangan ikani di wilayah ini yang tergolong "Cukup Tahan" dengan skor sebesar 32,35 , ini lebih dipengaruhi oleh indikator ketersediaan pangan ikani dan keamanan pangan ikani.

Tabel1. Ketahanan Pangan Ikani Rumah Tangga Perikanan Tangkap Skala Kecil di Kecamatan Cilincing, Jakarta Utara, 2008.

Table 1. Fish-food Security the Small-scale Fisheries Household in Subdistrict of Cilincing, North Jakarta, 2008.

\begin{tabular}{|c|c|c|c|}
\hline No. & Indikator/Indicators & $\begin{array}{l}\text { Klasifikasi/ } \\
\text { Classification }\end{array}$ & $\begin{array}{l}\text { Skorl } \\
\text { Score }\end{array}$ \\
\hline 1. & Ketersediaan pangan ikani/ Fish food availability & Tinggi/High & 10,55 \\
\hline 2. & Stabilitas pangan ikani/ Fish food stability & Sedang/Middle & 8,03 \\
\hline 3. & $\begin{array}{l}\text { Keterjangkauan pangan ikani/ Fish food } \\
\text { accessibility }\end{array}$ & Sedang/Middle & 7,90 \\
\hline 4. & Keamanan pangan ikani/Fish food safety & Tinggi/High & 5,87 \\
\hline $\begin{array}{l}\text { Tota } \\
\text { Tota }\end{array}$ & $\begin{array}{l}\text { ketahanan pangan ikani/ } \\
\text { of fish food security }\end{array}$ & $\begin{array}{c}\text { Cukup } \\
\text { tahan/Adeguate }\end{array}$ & 32,35 \\
\hline
\end{tabular}

Sumber: Data Primer diolah (2008)/Source: Primary Data Processed (2008)

\section{Tingkat Ketahanan Pangan Ikani Rumah Tangga Perikanan}

Ketahanan pangan ikani merupakan kondisi terpenuhinya pangan terhadap ikan bagi setiap rumah tangga, yang tercermin dari tersedianya ikan yang cukup jumlah maupun mutunya, aman, merata dan terjangkau. Kondisi ketahanan pangan ikani pada rumah tangga perikanan tangkap laut skala kecil di Kabupaten Cilincing, Jakarta Utara tergolong dalam klasifikasi "Cukup Tahan". Kondisi ini dipengaruhi oleh indikator ketersediaan pangan ikani, stabilitas pangan ikani, keterjangkauan pangan ikani dan keamanan pangan ikani. Pengklasifikasian tersebut didasarkan pada nilai relatif yang diperoleh dari hasil pengolahan. Setiap indikator pada
Korelasi Kondisi Sosial Ekonomi dengan Ketahanan Pangan Ikani

Hasil analisis hubungan antara peubahpeubah kondisi sosial ekonomi dengan tingkat ketahanan pangan ikani di lokasi penelitian tertera pada Tabel 2. Pada Tabel 2, dapat dilihat bahwa secara keseluruhan kondisi sosial ekonomi (pendidikan, budaya makan ikan, aset ekonomi dan pendapatan) rumah tangga di lokasi penelitian memiliki hubungan dengan arah positif yang nyata dengan tingkat ketahanan pangan ikani. Secara rinci hubungan kondisi sosial ekonomi tersebut dengan ketahanan pangan ikani masingmasing dijelaskan pada uraian selanjutnya.

\section{(1) Hubungan antara Pendidikan dengan}


Tabel 2. Hubungan antara Kondisi Sosial Ekonomi dengan Ketahanan Pangan Ikani di Cilincing, Jakarta Utara, 2008.

Table 2. Relationship between Socio-Economic Condition and Fish-food Security in Subdistrict of Cilincing, North Jakarta, 2008.

\begin{tabular}{|c|c|c|}
\hline $\begin{array}{l}\text { Hubungan Antar Peubah/ } \\
\text { Relationship Between Variables }\end{array}$ & $\begin{array}{c}\text { Koefisien Korelasi } \\
\text { Produk } \\
\text { Momen/Coefficients } \\
\text { Product Moment } \\
\text { Correlation }\end{array}$ & $\begin{array}{l}\text { Signifikansi/ } \\
\text { Significant } \\
(\alpha / 2)\end{array}$ \\
\hline $\begin{array}{l}\text { Pendidikan dan ketahanan pangan } \\
\text { ikani/Education and fish food security }\end{array}$ & 0,426 & $0,017\left(^{* *}\right)$ \\
\hline $\begin{array}{l}\text { Budaya makan ikan dan ketahanan pangan } \\
\text { ikani/Eating fish culture and fish food security }\end{array}$ & 0,515 & $0,003\left({ }^{* * *}\right)$ \\
\hline $\begin{array}{l}\text { Aset ekonomi dan ketahanan pangan ikani/ } \\
\text { Asset value and fish food security }\end{array}$ & 0,493 & $0,005\left({ }^{* * *}\right)$ \\
\hline $\begin{array}{l}\text { Pendapatan rumah tangga dan ketahanan } \\
\text { pangan ikani/Income household and fish food } \\
\text { security }\end{array}$ & 0,548 & $0,001\left(^{* * *}\right)$ \\
\hline
\end{tabular}

Sumber: Pengolahan Data Primer (2008)/Source: Primary Data Processed (2008)

Keterangan/Remarks: * *) nyata pada selang kepercayaan 90\%/significant $90 \%$

${ }^{* *}$ ) nyata pada selang kepercayaan $95 \% /$ significant $95 \%$

***) nyata pada selang kepercayaan 99\%/significant $99 \%$

ns) tidak nyata/insignificant

\section{Ketahanan Pangan Ikani}

Secara umum perilaku konsumsi makanan seseorang atau keluarga sangat erat dengan wawasan atau cara pandang yang dimiliki terhadap (sistem) nilai tindakan yang dilakukan. Jika ditelusuri lebih lanjut, sistem nilai tindakan tersebut dipengaruhi oleh pengalaman pada masa lalu yang berkaitan dengan pelayanan gizi/kesehatan/KB, ciri-ciri sosial yang dimiliki (umur, jenis/golongan etnik, pendidikan, pekerjaan dan sebagainya), dan informasi pangan, gizi dan kesehatan yang pernah diterimanya dari berbagai sumber (Susanto, 1994).

Selain itu, menurut Moehdji (1986) menyatakan bahwa tingkat pendidikan akan mempengaruhi konsumsi melalui pemilihan bahan pangan. Orang yang berpendidikan lebih tinggi cenderung memilih makanan yang lebih baik dalam jumlah dan mutunya dibandingkan mereka yang berpendidikan lebih rendah.

Dari hasil analisis, seperti tertera pada Tabel 2 diketahui terdapat hubungan yang nyata dengan arah positif antara peubah pendidikan dengan peubah ketahanan pangan ikani. Sebagaimana ditunjukkan oleh nilai koefisien sebesar 0,426 dengan selang kepercayaan sebesar $95 \%(\alpha / 2=0,017)$. Hal ini mengindikasikan bahwa semakin tinggi tingkat pendidikan rumah tangga berhubungan nyata dengan tingkat ketahanan pangan ikani rumah tangga yang semakin tinggi pula.

Akan tetapi, jika dikaitkan dengan kondisi di lapang dimana tingkat pendidikan rumah tangga nelayan skala kecil yang didominasi oleh responden yang tidak sekolah dan tidak tamat SD, maka untuk meningkatkan ketahanan pangan ikani di lokasi penelitian ini 
perlu memperhatikan pentingnya upaya peningkatan pendidikan bagi masyarakat nelayan setempat. Hal ini berdasarkan pada teori yang disampaikan oleh Moehdji, bahwa tingkat pendidikan akan mempengaruhi pola konsumsinya. Diharapkan dengan semakin tingginya tingkat pendidikan tersebut pada gilirannya akan meningkatkan ketahanan pangan ikaninya, sehingga nelayan semakin sadar akan pentingnya sumber protein dari hewani (ikan) untuk meningkatkan gizi.

\section{(2) Hubungan antara Budaya Makan Ikan dengan Ketahanan Pangan Ikani}

Masalah konsumsi pangan dan gizi bukanlah masalah yang berdiri sendiri tapi merupakan bagian dari suatu sistem yang ditentukan oleh berbagai faktor yang saling terkait, diantaranya faktor sosial budaya seperti kebiasaan makan (Sanjur, 1982).

Dari hasil analisis, seperti tertera pada Tabel 2 diketahui terdapat hubungan yang nyata dengan arah positif antara peubah budaya makan ikan dengan peubah ketahanan pangan ikani. Sebagaimana ditunjukkan oleh nilai koefisien korelasi Product Moment sebesar 0,515 dengan selang kepercayaan sebesar 99\% ( $\alpha / 2=$ 0,003). Hal ini mengindikasikan bahwa semakin tinggi budaya makan ikan rumah tangga berhubungan nyata dengan tingkat ketahanan pangan ikani rumah tangga yang semakin tinggi pula. Akan tetapi, bila dikaitkan dengan kondisi di lapang dimana budaya makan ikan rumah tangga nelayan skala kecil yang didominasi oleh kebiasaan makan responden yang lebih memilih pangan lain (non ikan). Oleh karena itu, untuk meningkatkan ketahanan pangan ikani di lokasi penelitian perlu adanya penyuluhan untuk menumbuhkan kesadaran dan kebiasaan makan ikan yang lebih baik lagi. Hal ini mengingat kandungan gizi terutama protein dari ikan yang tidak kalah besarnya dibandingkan dengan dari sumber protein lainnya.

(3) Hubungan antara Aset Ekonomi

\section{dengan Ketahanan Pangan Ikani}

Dari hasil analisis, seperti tertera pada Tabel 2 diketahui terdapat hubungan yang nyata dengan arah positif antara peubah aset ekonomi dengan peubah ketahanan pangan ikani. Sebagaimana ditunjukkan oleh nilai koefisien sebesar 0,493 dengan selang kepercayaan sebesar $99 \%(\alpha / 2=0,005)$. Hal ini mengindikasikan bahwa semakin tinggi aset ekonomi yang dimiliki oleh rumah tangga berhubungan nyata dengan tingkat ketahanan pangan ikani rumah tangga yang semakin tinggi pula.

Namun demikian, bila dikaitkan dengan kondisi di lapang dimana aset ekonomi rumah tangga nelayan skala kecil yang didominasi oleh responden yang memiliki aset televisi, jaring dan perahu, maka untuk meningkatkan ketahanan pangan ikani di lokasi penelitian ini dapat dilakukan dengan upaya mendorong kepemilikan perahu dan jaring yang lebih besar (banyak) baik dalam jumlah maupun kekuatannya sehingga mampu menjangkau daerah penangkapan ikan yang lebih jauh lagi.

\section{(4) Hubungan antara Pendapatan Rumah Tangga dengan Ketahanan Pangan Ikani}

Menurut Aziz (1990), bahwa ketahanan pangan rumah tangga dapat dicapai dengan pendapatan (daya beli) dan produksi pangan yang cukup. Sementara menurut Hasan (1995), resiko ketidaktahanan pangan tingkat rumah tangga timbul karena faktor rendahnya pendapatan atau rendahnya produksi dan ketersediaan pangan maupun faktor geografis.

Dari hasil analisis, seperti tertera pada Tabel 2 diketahui terdapat hubungan yang nyata dengan arah positif antara peubah pendapatan rumah tangga dengan peubah ketahanan pangan ikani. Sebagaimana ditunjukkan oleh nilai koefisien sebesar 0,548 dengan selang kepercayaan sebesar $99 \%(\alpha / 2$ $=0,001)$. Hal ini mengindikasikan bahwa semakin tinggi tingkat pendapatan rumah tangga berhubungan nyata dengan tingkat 
ketahanan pangan ikani rumah tangga yang semakin tinggi pula.

Akan tetapi, bila dikaitkan dengan kondisi di lapang dimana tingkat pendidikan rumah tangga nelayan skala kecil yang didominasi oleh responden yang pendapatannya tergolong rendah. Oleh karena itu, untuk meningkatkan ketahanan pangan ikani di lokasi penelitian ini selain dilakukan melalui upaya-upaya yang ada, dapat dilakukan pula dengan meningkatkan daya beli masyarakat yang ditunjukkan oleh tingginya tingkat pendapatan. Beberapa hal yang perlu diperhatikan terkait dengan upaya tersebut adalah diantaranya dengan mendorong kegiatan ekonomi masyarakat yang tidak hanya mengandalkan dari hasil tangkapan di laut tetapi juga didukung oleh pengembangan usaha di luar perikanan (off farm) yang dilakukan oleh anggota rumah tangga lainnya seperti oleh istri dari rumah tangga tersebut misalnya kegiatan pengolahan ikan ataupun berdagang ikan atau lainnya.

\section{KESIMPULAN DAN IMPLIKASI KEBIJAKAN}

\section{Kesimpulan}

Berdasarkan hasil analisis, tingkat ketahanan pangan ikani rumah tangga perikanan tangkap laut skala kecil di lokasi kasus penelitian ini tergolong dalam klasifikasi "cukup tahan". Hal ini didasarkan atas hubungan karakteristik sosial ekonomi, mulai dari faktor pendidikan, budaya makan ikan, aset yang dimiliki dan pendapatan/ pengeluaran rumah tangga. Ketahanan pangan ikani pada rumah tangga perikanan tangkap laut skala kecil memiliki hubungan positif dan nyata dengan peubah tingkat pendidikan, budaya makan ikan, aset ekonomi dan pendapatan rumah tangga.

\section{Implikasi Kebijakan}

Ketahanan pangan merupakan pilar bagi pembentukan sumberdaya manusia dan generasi yang berkualitas, sehingga perhatian terhadap masalah ketahanan pangan perlu mendapat perhatian yang lebih serius, agar tidak terjadi krisis ketahanan pangan yang berkepanjangan. Terdapat hubungan yang positif dan nyata antara karakteristik sosial ekonomi, khususnya tingkat pendidikan, budaya makan ikan, aset ekonomi dan pendapatan rumah tangga dengan ketahanan pangan ikani. Oleh karena itu, dalam melaksanakan pembangunan ketahanan pangan perlu ada tanggungjawab dan kerjasama antara masyarakat dengan pemerintah, karena masyarakat merupakan pelaku utama dalam pembangunan, sedangkan pemerintah berperan memberikan fasilitas dan sarana pendukung lainnya. Sehingga perlu adanya kebijakan pemerintah yang lebih mendorong kepada upaya penyelesaian permasalahan ketahanan pangan terutama pangan ikani melalui peningkatan mutu pendidikan dan pengetahuan pangan dan gizi, budaya makan ikan, peningkatan pendapatan rumah tangga dan aset rumah tangga, sehingga dapat lebih memiliki akses pangan yang lebih baik, menumbuhkan budaya makan ikan dan halhal lain yang mendukung ke arah peningkatan kondisi ketahanan pangan sumber ikani.

\section{DAFTAR PUSTAKA}

Anonimous. 2000. Rencana Aksi Pangan dan Gizi Nasional 2001-2005. Pemerintah Indonesia bekerjasama dengan World Health Organization.

. 2002. Peraturan Pemerintah

Republik Indonesia Nomor 68 Tahun 2000 Tentang Ketahanan Pangan. Sekretaris Negara RI. Jakarta. 2007. Monograph Desa Kalibaru, Kecamatan Cilincing, Jakarta Utara. 2009. Teori Analisis Korelasi Mengenal Analisis Korelasi. http://www.jonathansarwonoinfo/korelasi .diAkses Tanggal Agustus 2009

Aziz. 1990. Agriculture for the 1990's. Development Center Studies OECD. Paris. Dalam Berita Pangan,1(1): 22.

Hasan, I. 1995. Aku Cinta Makanan Indonesia 
dalam Rangka mewujudkan Ketahanan Pangan. Pengarahan Kursus Penyegar IImu Gizi dan Kongres Nasional PERSAGIX, 21-23 November. Bandung.

Mangkunegara, A. P. 2003, Perencanaan dan Pengembangan Sumber Daya Manusia. Refika Aditama. Bandung.

Moehdji, S. 1986. Pemeliharaan Gizi bayi dan anak. Batara, Jakarta.

Redaksi Sinar Grafika. 1997. Undang-Undang Pangan Nomor 7 Tahun 1996. Sinar Grafika.

Sanjur, D. 1982. Social and Cultural Perapektifes in Nutrition. Washington DC: Prentice Hall, Inc. New York, USA.

Sawit, M. H. 2007. Liberalisasi Pangan:
Ambisi dan Reaksi Dalam Putaran Doha WTO. Fakultas Ekonomi Universitas Indonesia. Jakarta.

Siegel, S. 1996. Non Parametric Statistics for Behavioral Sciences International Student Edition.

Susanto, D. 1994. Meningkatkan Strategi Komunikasi, Informasi dan Edukasi (KIE) dalam Pengentasan Masalah Gizi Kurang. Risalah Widyakarya Pangan dan Gizi IV. LIPI. Jakarta. 